\title{
Application of Land Management Right in Indonesiais against
}

\section{Law}

\author{
Tony $^{1}$, Prof. Yulia Mirwati, S.H., C.N., M.H. ${ }^{2}$, \\ Prof Dr. Runtung, S.H., M.Hum. ${ }^{3}$, Prof. Dr. Suhaidi, S.H., M.H ${ }^{4}$. \\ ${ }^{1}$ Post-Graduate, University of North Sumatera, Indonesia \\ ${ }^{2}$ Promotor, University of North Sumatera, Indonesia \\ ${ }^{3}$ co-Promotor, University of North Sumatera, Indonesia \\ ${ }^{4}$ co-Promotor, University of North Sumatera, Indonesia
}

\begin{abstract}
After its effectiveness for 51years in Indonesia, the Land Management Right appears to not having any legal constitutional ground that its implementation has often cause issues even controversies. This is because the land right of management regulated in the Regulation of the Minister of Agrarian Affairs No. 9/1965 is contrary to the Land Act No. 5/1960 which is the main legal provision which regulates land laws in Indonesia. It is recommended that those who directly deal with the Management Right in Indonesia attempt to get security and legal certainty for the sake of justice. In this case, the government and legislative body is expected to immediately issue new legal provisions which specifically regulates the Land Management Right in order to avoid the arbitrariness of the holders of the Right of Management toward the land right holders that come from the Management Right due to the agreement between both parties.
\end{abstract}

Keywords - Right of Management, Land, Indonesia, Effective, Against Law

\section{INTRODUCTION}

In the beginning of the effectiveness of the land Act No. 5/1960, the development of information and technology was very limited so that the range, regulation, and supervision became difficult in the level of Central Government. Consequently, the Central Government began to think of giving the authority of the Authorized Right by the State to autonomous regions and the adat communities in regulating and organizing land acquisition, land use, land inventory, and land maintenance outside of the Central Government. In reality, the Unitary State of the Republic of Indonesia has 17.504 islands. ${ }^{1}$ Besides that, at that time the Central Government planned to give opportunity to local governments to get their earnings by themselves. In this case, the Central Government attempted to give land rights to the local governments to be managed by them by using joint administration or assistance principle (medebewind) which is called the Management Right.

Therefore, the Management Right is the Authorized Right by the State which a part of its authority to implement; it is delegated to the right holders: the Ministry, local governments, State's Owned Enterprises, and Regional Government-Own Enterprises. The existence of the Management Right is not land rights according to the Land Act No. 5/1960; it is land rights which are under the regulation below the law such as the Regulation of the Minister of Agrarian Affairs No. 9/1965 on the Implementation of the Conversion of The Authorized Right by the State and the other regulations on the Policies. This Ministerial Regulation introduced the term, the Management Right, for the first time by referring to the Government Regulation No. 8/1953. According to A.P. Parlindungan, the term, the Management Right, is very unique because it did not use to be the Management Right but it was translated from Dutch, Beheersrecht (Management Law) which was translated to Indonesian, Hak penguasaan (the Authorized Right); this term had long been used. ${ }^{2}$ Government Regulation No. $5 / 1953$ at that time gave the authority and discretion to local governments to plan the allotment and the use (or it is more appropriate to use the terms, the use and the allotment because the use is 'use planning', or in urban planning, it is called zoning, and allotment is called bestemming which is specifically from the 'use planning'. 
Land right is the right to give an authority to use land given to other people or legal entity. Principally, the purpose of using a plot of land is to fulfill two types of need: to be cultivated and to be used as building something. The Land Act No. 5/1960 on Agrarian Affairs recognizes some rights on land which include Right of Ownership, Leasehold, Building Rights, and Right of Use. In the development of the national Land Act, it is also recognized the Management Right. When it is viewed from the regulation in the Land Act No. 5/1960, there is no explicit provision which states the "Management Right" as one of the land rights. The Land Act No. 5/1960 only mentions the term "management" in its General Explanation II, figure 2 of the Land Act No. 5/1960. In this case, Boedi Harsono points out that besides it is for local governments and adat (customary) community, and the delegation of authority in implementing a part of the State's authority on land, it can also be done for authoritative agencies, State enterprises, and local companies by giving certain land tenure which is popularly known as the Management Right.

Article 6 of the Regulation of the Minister of Agrarian Affairs No. 9/1965 states that the term, the Management Right, used to have the authority to

1. Plan the allotment of land use;

2. Use the land for the need of executing duties;

3. Receive income money/compensation and/or annual fee.

\section{RESEARCH METHODOLOGY}

This research (axiology) is to review any regulations that administer the Management Right nationally in Indonesia in order to increase the feasibility of jurisprudence in applying the practices, specifically in supporting the development of the national laws in Indonesia, especially about the regulations on the Management Right which is regarded as urgent. ${ }^{3}$

This research is expected to have its significance in either theoretically or practically.

\section{Theoretically}

The significance of this research is to provide critics and contributions in the development of jurisprudence in agrarian affairs, specifically in order to reform Law on Agrarian Affairs No. $5 / 1960$, especially in its judicial aspect on the Management Right.

\section{Practically}

It was aimed to provide input for regulators, especially legislative body, to become the references and consideration in legal protection for the holders of Land Management Right.

\section{Theoretical Analysis}

Function of the theory is to provide an analytical device which enables necessary questions to be asked and enables tentative answers to be given. Theory enables the development of a paradigm ${ }^{4}$ which provides coherence and consistency for every argumentation about rights and also contributes a model which can be used to measure the presumed rights. This theory also provides the mechanism which can be used to accurately determine the limitation of the right in which existence has been agreed. $^{5} \quad$ According to Otje Salman and Anthon F. Susanto, talking about theory is the same as talking about law, there is indeed no standard and everlasting definition. Generally when we discuss a theory, we will be faced by two kinds of reality: in abstracto reality which exists in imaginative idea and its point of view which takes the form of in concreto reality exists in sensory experience. In the literature, some experts use the word 'theory' to show a thinking building which is systematic, organized, logic (rational), empirical (reality), and symbolic. ${ }^{6}$ A normative judicial research, according to Bahder Johan Nasution, the result that are expected from the assessment is basically law argumentation which will be directed to the formulation of a theory. Therefore, normative judicial research develops a legal concept in order to organize a very important theory. The activity to develop this concept constitutes observation and documentation in order to break off the legal elements that are essential and inessential and also to group according to the similarity of certain legal concepts. ${ }^{7}$

Modern theories in Grand Western Theory on the objective of law consists of :

a. Standard priority theory; the objective of law includes

1.Justice

2.Usefulness 
3.Legal certainty

a. Casuistic priority theory

Jurisprudence is a science and belong in Applied Science Group, however in additional, jurisprudence has special position in scientific classification, not only because it has had a long history which establishes it compared with the other sciences, but also because its nature as a normative science and its direct impact on human and public life that is adhered to their characteristics and problems (inherent problems in their everyday life) which have put forward and guide their advancement and development. Jurisprudence which is included in Applied Science Group has its own characteristics. Besides what has been explained above, its analytical objects are concerned with certain behaviors which its compliance does not entirely depends on their own free will but it can also be forced by public power. ${ }^{8}$

\section{Application of Law}

According to Mukti Fajar and Yulianto Achmad, the advantages of judicial research are:

a. To determine the correlation of law and legal status of the stakeholders in a juristic event.

b. To provide valuation of law (justification) on a juristic event. Whether it is wrong, right, or ought to be done according to law.

c. To make a correction and to keep consistency of the system of norm toward fundamental norms, principles, doctrines, contracts, and legal provisions which are in effect and will be put into effect. $^{9}$

This can be viewed from the limitations which are stated by some legal experts as follows:

a. According to P. Borst, a law is the entire regulations for human behavior and action in society, in which the implementation can be forced in order to obtain structure or peace and justice.

b. According to Van Kan, law is the entire regulations of life which are coercion to protect human's interest in society.

c. According to Prof. Paul Scholten, besides the elements of verlof (fulough), belofte (pledge), and disposition, and Recht is bevel (right order). Bevel is a comand which means that a law is a coercion. $^{10}$

As one of the legal aspects in life, a law is certainty which means that its intention is to create certainty in the relationship among people in society. One of the components that is closely related to the certainty is where the law does came from. The certainty about where a law came from becomes important since law is becoming more of a formal institution. In the context of its development, there is an important question about which sources that is considered as valid. ${ }^{11}$

Hans Kelsen points out that a law is a requirement which regulates human behavior as a rational creature. In this case, what does matter in law is not about what the law ought to be, but is about what the law is. Therefore, even though a law is Sollenkategorie (a must category), what is used is positive law (ius constitutum), not a law which is aspired (ius constituendum). ${ }^{12}$

The concept of Friedrich Julius Stahl's thought on the State law is highly influencing until these days. According to Stahl, the duty of a State is not just as a night guard but it has vastly developed and actively meddles in the economics, socials, and cultural fields. This kind of concept is known as Welvaarstaat or welfare state.

The government should organize the distribution of the State's assets in order that there will be no famine in Indonesia by providing the needs for food, clothing, and housing; there will be no people who die because they cannot afford to pay their hospital fee. It can be said that welfare state comprises the element of socialism and prioritizes the welfare in politics and economy. It is also considered that a welfare state comprises the principle of liberty, the principle of equality in rights, the principle of fraternity or the principle of mutuality. The principles of fraternity and mutuality can be treated equally to the principle of consanguinity or working together in mutual cooperation. ${ }^{13}$

According to Bo Rohstein, based on the practice in the State Organization, there are two approach models in implementing the theory of welfare state concerning bureaucracy, they are:

a. The State directs every resource to fulfill the needs which are most vital to its people. In this case, the State needs to highly involved and the bureaucracy to govern every aspect of people's social life through the instrument of organizing and licensing. It seems that in this model, people cannot 
properly develop their creativityy, and powerful involvement of bureaucracy will cause vulnerability to misuse authority.

b. Bureaucracy is not much involved in people's social life. Most important is establishing "criteria" clearly so that welfare can be carried out righteously. In this case, bureaucracy controls its people through the instrument of taxation. By using this model, people will be able to develop their creativity because it has many public choices. ${ }^{14}$ To that end, Indonesia as a constitutional state principally confirms that all enacted legal products have to have their legal grounds or higher enactment so that lower regulations is only a regulation implementation and it is forbidden to make individual regulations apart from what has been regulated by enactment or by higher regulations.

\section{DISCUSSION}

According to A.P. Parlindungan, the government was committed to amend regulations on land so that it became status quo in issuing new eigendom (property) rights. (Before the Land Act No. 5/1060, they were still controlled by Burgerlij wetboek or Civil Code regime); however, because of the urban development, City Administrative needed lands for executing its function. Likewise, there were many deviations that of lands bought by people for government's needs, included as well those land that were Authorized Right property of Local Government is easily sell-able and transfer-able without going through necessary process, with the result that the Government issued the Government Regulation No. 8/1953. ${ }^{15}$ Article 2, paragraph 4 of the Land Act No. 5/1060 states that:

"The Authorized Right of the State can be sanctioned to local governments and the Custom Law communities as long as it is not contrary to the national interest, according to the Government regulations." The citation above can arouse double interpretation. When it is read literally which is giving land management to an authorized institution are then systematically associated to Article 4, paragraph 2 of the Land Act No. 5/1060 regarding the problem of the implementation of "Authorization by the State," the word, 'management' tends to signify as a function. However, since the formulation is connected to the subordinate clause preceded it, the giving of a plot of land is related to various kinds of land rights, and its systematic interpretation of the word, management can be led to its connotation as the right. However, the correlation with the violation against Article 16, paragraph 1, letter (h) of the Land Act No. 5/1960 is indubitable because Article 16, paragraph 1, letter (h) of the Land Act No. 5/1960 clearly states that "the other rights" which are not included these rights will be stipulated as a law and with its temporary rights as it is stipulated in Article 53 of the Land Act No. 5/1960. ${ }^{16}$ The subject of the Authorized Right is the Unitary State of the Republic of Indonesia as an authorized organization for all Indonesian people comprises land in its territory, either the land which has or has not been owned the right to it with individual rights. Land which has yet had the individual right to is called as land which is powered directly by the State (in the administrative term it is called State's land), while the land which has had its rights with individual rights is called land rights with a name of the right in it; for example, land ownership. ${ }^{17}$ Authorization of land can be divided into two aspects: legal aspect and physical aspect. Authorization of land in legal aspect is based on a right which is protected by law; its competence is generally given to the right holder who controls the land physically. Nevertheless, physical authorization is not always adhered to those who control it legally. ${ }^{18}$ For example, in the land which is leased, legal control is held by land owner, while its physical control is on its tenant. Article 28 of the Regulation of the Minister of Internal Affairs No. 5/1975 once again states the meaning of the Management Right as it is formulated in Article 6 of the Regulation of the Minister of Agrarian Affairs No. 5/1973 which states that the Management Right is the right on state land as it is stipulated in the regulation of the Minister of Agrarian Affairs No. 9/1965 which authorize its holder to:

1. Plan his land acquisition and utility;

2. Use the land to be cultivated;

3. Hand over some parts of the land to the third party with the Right of Use for a six year-period;

4. Receive income money/annual fee.

Management Right does not have any term of ownership, and it is given only on state land which is controlled by the local government, the State's Owned Enterprise, and Local GovernmentOwned Enterprise which is aimed to control zoning and land use in order that it will be in accordance with its layout planning. ${ }^{19}$ 
According to Urip Santoso when it is reviewed from its aspect, the characteristics of land rights owned by the Management Right are as follows:

a. In the Land Act No. 5/1960 and in the Government Regulation No. 40/1996, there is land right which is known as the Right of Use and not the Right of Disposal. This land right is the Right of Use which right is only to use a plot of land for execution of duties or venture; it cannot be transferred in any forms and cannot be used as a mortgage for debt with hypothecation. This land right is the Right of Use owned by Departments, Government Institutions of Non Department, Provincial Administration, District/Town Administration, Foreign Country Representatives, International Agency Representatives, Religious Boards, and Social Boards.

b.Land Rights can be transferred or handed over by the right holder for public interest or the interests of other parties with or without any compensation. The Management Right can also be transferred or handed over by the right holder for public interest or the interests of other parties with or without any compensation;

c. Land rights can be wiped off because the land is abandoned by the right holder as it is regulated in the Land Act No. 5/1960 and in the Government Regulation No. 40/1996. The Management Right can also be terminated because the land is abandoned by the right holder as it is regulated in the Government Regulation No. 36/1998 which has been revoked and amended by the Government Regulation No. $11 / 2010 .^{20}$

The guarantee for legal certainty includes the certainty on the status of the Management Right, the subject of the Management Right, and the object of the Management Right. The guarantee for legal protection for the holder of the Management Right is that he will have the sense of security in controlling his land Management Right since he does not have any obstacles or claim from other people. Legal protection will be obtained by the holder of the Management Right as far as there is no legal defect which includes procedural defect, authoritative defect, or substantial defect in the issuance of the Management Right. ${ }^{21} \quad$ Yance Arizona points out that legal certainty normatively is when a regulation is made and enacted with certainty because it is regulated normatively and logically. What it means by certainty is that it does not bring about any doubt (multi-interpretation) and logical which means that it becomes a system of norm with another norm so that they are not overlapping and or causing a conflict in norms. Conflict in norm caused by uncertainty of regulation can be in the form of norm contestation, norm reduction, or norm distortion. ${ }^{22}$ A system is a totality which consists of components or elements which are different from another but interrelated in a pattern so that they can be applied consistently. ${ }^{23}$ Therefore, legal guarantee and certainty have to be included and organized in the norms which are systematic, consistent, and relevant to one another so that every regulation should be interrelated and complimentary to one another; in other words, they are not independent which make them contradictory to one another. The Management Right is not a kind of land rights which are known in Law on Agrarian Affairs and organized in law which organizes land; actually, has rapidly developed. Therefore, the urgency of the Management Right as a right of a land needs to be reconsidered because government agencies and State-Owned Enterprises/Regional Government-Owned Enterprises need land to be given its Building Rights and the Right of Use. Actually, the Management Right for State-Owned Enterprises and Regional Government-Owned Enterprises is not needed anymore since both enterprises' assets are separated from the central government/regional government, and they are profitable. If it is maintained as land rights, the regulation should be organized in laws in order to get legal certainty and to have powerful effectiveness. Therefore, either the House of Representatives or the Government should be firm in the existence of the Management Right in the substance of the draft bill on land which is being discussed in the House of Representatives of the Republic of Indonesia. ${ }^{24}$ The existence of the Management Right as a public right is part of the Authorized Right by the State. It is an administrative right in which the holder of the Management Right is given the authority to organize and manage the land which is delegated by the State. ${ }^{25}$ Ateng Syafrudin points out that there is the difference between gezag or authority and bevoegheid or competence. We should distinguish these two terms. Authority is what it is called by formal authority which comes from and is given by law, while competence is only about a certain onderdeel (part) of authority. There are rechtsbevoegdheden (competences) in an authority. ${ }^{26}$ 
However, when we talk about authority, there is also an action without authority which is known as the term, ultra vires which means beyond one's legal power or authority that causes jurisdictional errors render the decision. According to Blak, ultra vires is an act performed without any authority to act on subject. Acts are beyond the scope of the powers of a corporation, as defined by its charter or laws of state of incorporation. Foulkes points out that an ultra vires act is where the person or body that does it has not been properly appointed or constituted; an act will be ultra vires even if it is done by the proper person properly appointed when he exceeds the power given him. ${ }^{27}$

\section{CONCLUSION AND SUGGESTION}

\section{Conclusion.}

a. The Management Right which is a delegation of authority and the implementation of authorization from the principle of the Authorized Right by the State, in its implementation in the field becomes a paradox against the principle itself. The Management Right, which is the implementation of a part of the competence because of its medebewind (joint administration) of the Authorized Right by the State, in its real implementation, has surpassed the given authority and even surpassed its main authority, the Authorized Right by the State, which includes public right and individual right as if domain verklaring principle were in effect. ${ }^{28}$

b. Legal domicile of the holder of land Management Right, like the holder of Building Rights/the Right of Use, in its operational implementation, is limited in using the rights. This limitation will be seen when the holder of Building Rights/the Right of Use is to prolong his rights which has overdue, use the land as collateral, or transfer the land to another person; in this case, he has to get the approval from the holder of the Management Right. When it is traced its legal ground, the Management Right comes from the Authorized Right by the State which a part of its authority is given to the holder of the Management Right that does not require limitation as what has been determined by the holder of the Rights of Management.

c. The implementation of the Management Right arouses land problems because of distortion principle and norm reduction in some regulations which regulate the Management Right, especially the regulation of the Minister of Agrarian Affairs No. 9/1965 which converses the Authorized Right to become the Right of Use and the Management Right where the Management Right was not recognized in the Land Act No. 5/1960. Meanwhile, the regulation on the Management Right is urgently needed nowadays; therefore, in Article 1, paragraph 8 and Article 98 of Draft Bill on Land there drafted the Bill of Land specifically in the Management Right. The regulation on the Management Right is separated from the other regulations on land rights such as Ownership, Leasehold, Building Rights, the Right of Use, and so on. It shows that in the new Draft Bill on Land, the Management Right is placed as a function and not as a right as what occurs in the other land rights. Therefore, the Management Right is returned to public jurisdiction which is the delegation of authority from the Authorized Right by the State.

\section{Suggestions}

a. As technological advancement develops rapidly, the regulation on land acquisition and land use will practically not undergoing any difficulty when land control and supervision are performed by the central government so that delegation of authority is not needed anymore. Therefore, it is the right time now for the central government to consider returning the Management Right to its original place, the Authorized by the State.

b. However, if the existence of the Management Right has to be maintained, in order that the Management Right has strong legal ground in the future, it is recommended that laws or government regulations which specifically regulate the Management Right stipulated in Article 2, paragraph 4 of the Land Act No. 5/1960, while nomenclature of the Management Right should be changed to Management Function, Management Control, or the Authorized Right by Local Government so that there will be no misinterpretation by common people.

c. Land problems in their implementation of any legal act in land which has the status of the Management Right, especially in the transfer of land from the holder of the Management Right to another party, become the collateral, and when the land Management Right will be prolonged, it is 
expired. Therefore, it is recommended that it be unnecessary to request for the approval of the holder of the Management Right. All of the rights such as Building Right/the Right of Use and the other rights on the land of the Authorized Right by the State should be treated equal.

\section{REFERENCES}

[1] https://www.dkn.go.id/ruang-opini/9/jumlah-pulau-di-indonesia.html, accessed on January 18, 2015; written by Dody Usodo Hargo, entitled, Jumlah Pulau di Indonesia.

[2] A.P Parlindungan, Hak Pengelolaan Menurut Sistem Undang Undang Pokok Agraria No. 5 Tahun 1960 (Law on Agrarian Affairs) Revision Ed., CV. Bandung: Mandar Maju, 2015, p. 2.

[3] Bernard Arief Sidharta, Refleksi Tentang Struktur Ilmu Hukum, Bandung: Mandar Maju, 2009, p. 42.

[4] According to Thomas S. Kuhn, paradigm is a basic assumption and general theoretical assumption (as a source of value) so that it can be a legal ground, method, and implementation in knowledge which determines the nature and the characteristics of the knowledge itself. He points out that scientific development and advancement is revolutionary and not cumulative as what used to be thought. Revolutionary science initially involves paradigm domain, the way of viewing the world and the examples of performance or concrete scientific practice. The procedure of paradigm and the incidence of scientific revolution can be described in some stages as follows: in the first stage, this paradigm guides and directs scientific activities in the period of normal science. Here, scientists have opportunity to analyze and to develop paradigm as a scientific model they are involved in detail and profoundly. In this stage, the scientists are not critical toward paradigm which guides their scientific activities. During their scientific activities, scientists encounter various phenomena which cannot be explained by the used paradigm as the guidance or direction for their scientific activities which is called anomaly. Anomaly is a condition which indicates disparity between reality (phenomena) and the used paradigm. In the second stage, the accumulation of anomalies brings about scientists' crisis of confidence toward paradigm. Paradigm begins to raise questions and scientists begin to come out from the path of normal science. In the third stage, scientists can return to the same scientific methods by broadening and developing a counter paradigm which is considered being able to cope with problems and to guide the next scientific activities. The process from the old paradigm to the new one is called scientific revolution. See Surajiyo, Filsafat Ilmu dan Perkembangannya di Indonesia, Jakarta: Bumi Aksara, 2010, p.157.

[5] Scott Davidson, Hak Asasi Manusia, Jakarta: 2008, p. 34.

[6] Sabian Utsman, Metodologi Penelitian Hukum Progresif, Yogyakarta: Pustaka Pelajar, 2014, p. 52.

[7] Bahder Johan Nasution, Metode Penelitian Ilmu Hukum, Bandung: Mandar Maju, 2008, hlm. 108.

[8] Bernard Arief Sidharta, Refleksi Tentang Struktur Ilmu Hukum, Bandung: Mandar Maju, 2009, p.113.

[9] Mukti Fajar dan Yulianto Achmad, Dualisme Penelitian Hukum Normatif \& Empiris,Yoyakarta: Pustaka Pelajar, 2010, p. 41.

[10] R. Soeroso, Pengantar Ilmu Hukum, Jakarta: Sinar Grafika, 2014, p. 66.

[11] Satjipto Rahardjo, Ilmu Hukum, Bandung: Citra Aditya Bakti, 2012, p. 81.

[12] Jarot Widya Muliawan, Pemberian Hak Milik Untuk Rumah Tinggal, Sebuah Kajian Normatif Untuk Keadilan Bagi Masyarakat, Yogyakarta: Buku Litera, 2015, p.37.

[13] RMAB Kusuma, "Negara Kesejahteraan dan Jaminan Sosial," Constitution Journal, Vol.3, February, 2006, Jakarta: Constitutional Court, 2006, p. 160.

[14] Taufiq Effendi, Reformasi Birokrasi dan Iklim Investasi, Jakarta: Konstitusi Press (Konpress), 2013, pp. 44-45.

[15] ibid., p. 5.

[16] Hetty Sofiati, Laporan Akhir Tim Pengkajian Masalah Hukum Hak Pengelolaan Atas Tanah Negara, Jakarta: The National Law Development Biard of the Department of Law and Human Rights, 2004, p. 49. 
[17] WibowoTunardy, http://www.hukum.com/macam-macam-hak-penguasaan-atas-tanah, accessed on May 5, 2016.

[18] http://www.jurnalhukum.com/macam-macam-hak-penguasaan-atas-tanah, accessed on May 15, 2016

[19] Ivan Ari, http://www.hukumproperti.com/2009/12/10/status-hukum-suatu-properti-di-atas-hakpengelolaan-lahan, accessed on May 3, 2016.

[20] Urip Santoso, Eksistensi Hak Pengelolaan Dalam Hukum Tanah Nasional, http:// download.portalgaruda.org, Mimbar Hukum, Vol. 24, Number 2, June, 2012, p. 286.

[21] file:///Users/users/Downloads/15020-36077-1-PB\%20(2).pdf, accessed on December 31, 2016, written by Yuheni Hasariah Siregar, entitled, Mekanisme Penggunaan Sebagian Hak Pengelolaan (HPL) Bandara Kuala Namo Oleh Pihak Ketiga.

[22] http://yancearizona.net/2008/04/13/apa-itu-kepastian-hukum, accessed on Friday, March 11, 2016.

[23] Puri Sentania, Pengertian Sistem Hukum Nasional, http://www.academia.edu/6918898/, accessed on Saturday, March 11, 2016.

[24] file:///Users/users/Downloads/212-418-1-SM\%20(3).pdf, accessed on January 1, 2017, written by Sulasi Rongiyati, entitled, Pemanfaatan Hak Pengelolaan atas Tanah oleh Pihak Ketiga.

[25] http://dinamikahukum.fh.unsoed.ac.id/index.php/JDH/article/viewFile/104/53, accessed on March 15, 2015, written by Elita Rahmi, entitled, Eksistensi Hak pengelolaan Atas Tanah (HPL) Dan Realitas Pembangunan Indonesia.

[26] Ateng Syafrudin, "Menuju Penyelenggaraan Pemerintahan Negara Yang Bersih Dan Bertanggung Jawab," Jurnal Pro Justisia, W Edition, Bandung: Parahyangan University, 2000, p. 22

[27] http://www.infodiknas.com/wp-content/uploads/2016/01/, accessed on January 2, 2017, written by Abdul Rokhim, entitled by Batas-Batas Wewenang Direksi Dalam Mengurus Perseroan.

[28] Land which has no owner will automatically belong to the State. 